Florida International University

FIU Digital Commons

$3-25-2020$

\title{
Mirror, Mirror: Disrupting Cinema in "Cléo from 5 to 7" (1962) and "A Girl Walks Home Alone at Night" (2014)
}

Stephanie M. Janania

Florida International University, sjana003@fiu.edu

Follow this and additional works at: https://digitalcommons.fiu.edu/etd

Part of the Feminist, Gender, and Sexuality Studies Commons, Film and Media Studies Commons, and the Other English Language and Literature Commons

\section{Recommended Citation}

Janania, Stephanie M., "Mirror, Mirror: Disrupting Cinema in "Cléo from 5 to 7" (1962) and "A Girl Walks Home Alone at Night" (2014)" (2020). FIU Electronic Theses and Dissertations. 4405.

https://digitalcommons.fiu.edu/etd/4405

This work is brought to you for free and open access by the University Graduate School at FIU Digital Commons. It has been accepted for inclusion in FIU Electronic Theses and Dissertations by an authorized administrator of FIU Digital Commons. For more information, please contact dcc@fiu.edu. 


\title{
FLORIDA INTERNATIONAL UNIVERSITY \\ Miami, Florida
}

\section{MIRROR, MIRROR: DISRUPTING CINEMA IN “CLÉO FROM 5 TO 7” (1962) AND \\ “A GIRL WALKS HOME ALONE AT NIGHT” (2014)}

\author{
A thesis submitted in partial fulfillment of \\ the requirements for the degree of \\ MASTER OF ARTS \\ in \\ ENGLISH \\ by
}

Stephanie Marie Janania 
To: Dean Michael R. Heithaus

College of Arts, Sciences and Education

This thesis, written by Stephanie Marie Janania, and entitled Mirror, Mirror: Disrupting Cinema in "Cléo From 5 to 7" (1962) and "A Girl Walks Home Alone at Night" (2014), having been approved in respect to style and intellectual content, is referred to you for judgment.

We have read this thesis and recommend that it be approved.

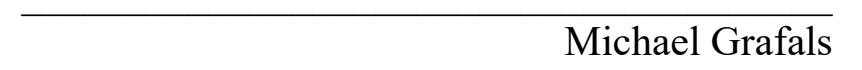

Andrew Strycharski, Co-Major Professor

Anne Margaret Castro, Co-Major Professor

Date of Defense: March 25, 2020

The thesis of Stephanie Marie Janania is approved.

Dean Michael R. Heithaus

College of Arts, Sciences and Education

Andrés G. Gil

Vice President for Research and Economic Development and Dean of the University Graduate School

Florida International University, 2020 


\author{
ABSTRACT OF THE THESIS \\ MIRROR, MIRROR: DISRUPTING CINEMA IN “CLÉO FROM 5 TO 7” (1962) AND \\ “A GIRL WALKS HOME ALONE AT NIGHT” (2014) \\ by
}

Stephanie Marie Janania

Florida International University, 2020

Miami, Florida

Professor Anne Margaret Castro, Co-Major Professor

Professor Andrew Strycharski, Co-Major Professor

"Mirror, Mirror" deconstructs the concept of mirror-like cinema: a cinema that relies on realistic elements and seamless editing for viewers to identify with. Mirror-like cinema dominates mainstream films creating a mirror and a reflection where women can be marginalized and objectified. Through the women directed films "Cléo from 5 to 7" (1962) and "A Girl Walks Home Alone at Night" (2014) identification with the cinematic reflection is challenged. Both films seemingly show Jacque Lacan's concept of the mirror stage, but disrupt the reflection through their editing, mise en scène, and the actions of their women protagonists. These disruptions exemplify the mirror being fragmented thus proving film is not always a reflection but can be a representation of one's subjective reality. 


\section{TABLE OF CONTENTS}

SECTION

PAGE

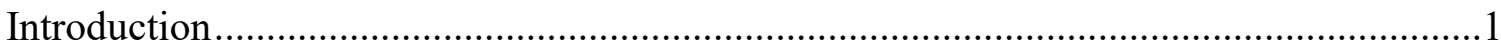

Cléo and the Mirror Stage ...............................................................................................

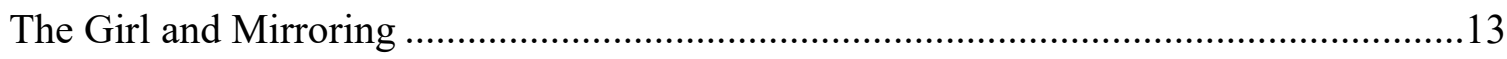

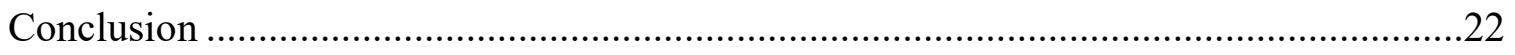

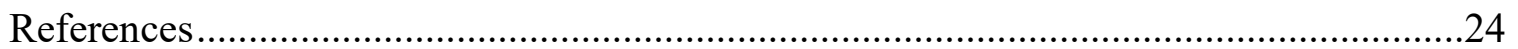




\section{Introduction:}

A cursory Google search for Joker (2019) will lead to a myriad of different articles all with the same wording. "The Joker - A Haunting Reflection Of Our Modern World” or "“Joker' Reveals a Reflection of Madness" or even "Joker (2019) Film Review - A Dark Reflection of Our Broken Society.” All the articles read the same. Joker is a reflection of the oppression, class conflicts, and underlying fear of mass violence the average 2019/2020 American individual experiences. To a white male heterosexual viewer, the film could easily look like a reflection. In Joker, a man who has been beaten down by the system to the point of breaking may look "mirror-like" to that spectator. However, when considering how women characters are sidelined narratively, sexually ogled after, and are responsible for a man's mental state, would the women in the audience see a reflection of their modern times? Do the women watching mainstream cinema see a reflection at all?

Mainstream directors often follow a "seamless," almost invisible type of editing style where a viewer can be consumed and be fully immersed in the narrative. According to Laura Mulvey in her seminal work, "Visual Pleasure," "Camera technology (as exemplified by deep focus in particular) and camera movements (determined by action of the protagonist), combined with invisible editing (demanded by realism) all tend to blur the limits of a screen space" (63). The spectator is meant to identify with the reflection the film creates. Mainstream directed films strive to create a mirror of reality that an audience member can see themselves in and not turn away from. However, Mulvey emphasizes that a majority of cinematic narrative is dominated by the male protagonist (63). In 2019,43 of the top 100 grossing films were led or co-lead by a woman 
protagonist which was an all-time high (Inclusion Initiative). In retrospect, this milestone may seem like progress, but the reality is the women in these narratives are largely directed and influenced by patriarchal standards such as being constrained to romantic plotlines (Star Wars: Rise of Skywalker) or striving to be objects of desire (What Men Want). Even the number of women directed films was at an all-time high, yet they only accounted for $10 \%$ of the films made in 2019. (Srikanth) Women representation can still be seen as scarce. Therefore, a woman spectator may not recognize the reflections of mainstream films but is often expected that she must recognize the reflection by the filmmakers.

The strides made for a more representational cinema has been in due part to feminist film critics and feminist filmmakers who present "specific challenges to cinematic codes and narrative conventions of illusionist cinema." (4 "Feminism and Film: Critical Approaches") Feminist filmmaking's goal, then, is to disrupt the male orientated reflection. Agnes Varda, French woman director who helped define the French New Wave, in her interview with Film Comment agrees that films cannot be "seamless." She tries to “[...]make a cinema in which people are not 'stolen.' I don't steal you. I like people to remain themselves in the theater and feel that maybe they'll enjoy themselves, maybe they'll cry, but that they'll have something to say[...]I like the idea you remain yourself, conscious of who you are." Varda believes a viewer should not be "stolen" by the screen. There should be no seamlessness from screen to life. Varda's filmmaking, then, has no intention of wanting to employ a mirror-like cinema. Varda, in fact, wants viewers to remember that films are not a reflection of our reality, but a "reproduction." It is a representation. I would argue film does not reflect our reality, but it is a subjective 
representation of it. It is only one angle to view reality. It does not define an individual or their circumstances

In "Mirror/Mirror" I will analyze two women directed films, Cléo from 5 to 7 (1962) directed by Agnes Varda and A Girl Walks Home Alone at Night (2014) directed by Ana Lily Amirpour, to demonstrate how mirrors and mirror-like cinema can be disrupted through conventions including editing, mise en scène, and the actions of the woman protagonists. Both films are exemplary works of the new waves they participate in. Cléo from 5 to 7 shows off how directors of the French New Wave "[...]broke traditional narrative conventions, favouring arresting and stylish techniques[...] (21 Wiegand) while $A$ Girl Walks Home Alone at Night emphasizes the importance of a "[...] mediating tool for socialization of a diverse audience to contemporary gender issues [...]" (1 Shahrokhi) The films have broken previous molds of filmmaking and have women protagonists lead the way to disrupting the restricting norms.

Post-Lacanian psychoanalytic tradition of the mirror leads "Mirror/Mirror"s analysis of mirror-like cinema. Lacan's concept of the mirror stage highlights how cinema may be a mirror, but the two films go beyond a Lacanian reading through their women protagonists. At the forefront, both films may seem to follow the mirror stage and mirror-like cinema, but it is through Cléo's existential crisis and The Girl's mirror characteristics that put forth representation versus reflection of a whole one viewing of reality.

\section{Cléo and the Mirror Stage:}

Cléo from 5 to 7 begins with Florence 'Cléo' Victoire, a singer from Paris, getting her tarot card reading done. The psychic who reads her life pauses at one card where a 
woman is dressed and dolled up (2:32). "That's you there," she states. Cléo, further wanting more asks, "Why?" The woman responds with, "The cards are difficult to read." The interaction is the basis for all of Cléo's conflicts throughout the film. Cléo wants to have a definitive answer of herself and her life but cannot get one. Prior to this meeting, Cléo received news that she may be dying which fills her with fear that her beauty will be gone and lost forever. Cléo consistently gazes into mirrors making sure that her tightfitting dress and her bun are always spot on. To Cléo, the mirror reaffirms her beauty, but it is also the main point of loss. Cléo despairs that her illness is shown on her face. At 7:51 she turns to the mirror and vows that if she does look ill, she would kill herself. Later on at 10:14, she is using her compact mirror to fix her makeup. Only a couple of minutes from gazing into the mirror and Cléo needs to see her reflection again to reaffirm that she still looks okay and that her beauty is intact. The dire need to consistently check herself in the mirror showcases how she truly is afraid she has lost the reflection of her beauty in the mirror.

The mirror permeates Varda's other works. In Varda's documentary Jane B. par Agnes V. (1987), Varda documents Jane Berkins, a famous British and French actress/singer for a year and a half giving the viewer multiple perspectives to "...consider all sides and facets of Jane" (314 McFadden). The spectator is first introduced to the concept of the mirror as camera five minutes into the film. In a cafe, Varda interviews Jane, but Jane is embarrassed to look directly into the camera lens when answering Varda's questions. Varda tries to recontextualize the camera as a mirror, but Jane insists that, "No, you don't look at others in a mirror, you look at yourself." The film jump-cuts to Jane looking into a mirror in the middle of the forest. Varda begins to explain how she 
is not "alone in the mirror" as the camera pans to reveal her and her crew. Varda illuminates the idea of a subject never being alone on both film and mirror. Varda and her crew are there alongside Jane demonstrating that she is consistently surrounded by others. I contend, then, that when a subject is staring into the mirror, there is always another person looking alongside it.

Jacque Lacan's concept of the mirror stage (also known as the mirror phase) criticizes Jane's idea of the reflection standing alone. The mirror stage is the identification of being a subject in the world ( 76 "The Mirror Stage as Formative of the Function"). A six-month-old infant (always identified as a 'he' for Lacan) first believes that he is everything around the room. When the child looks in the mother's eyes or a mirror, he recognizes himself in the reflected image and he believes he is whole. The child assumes the image he sees. Similar to Jane B., when Jane looks into the mirror, she has become the "I" and believes that the "I" is in isolation. She believes that the "I" lives in a vacuum and stands alone. The "I," for her, is whole which brings the subject in what Lacan would call the Imaginary world.

In the Lacanian Symbolic, sense, though, once the child has assumed his own image, he must turn to the mother who is able to "ratify this image" (119 Evans). The Symbolic world begins once the mother (also known as the big Other) of the child reaffirms that the reflection belongs to the child. The child, then, is a being in the world. The child has now become a subject because of the mother's recognition (98 Moi). Entering the Symbolic world also means the child is not a whole being in the world creating a gap between identity and the reflection. The child does not live in a vacuum. Now, he realizes that his identification is fragmented, and he can never be whole. 
Returning to the scene in Jane B. par Agnes $V$., after Jane declares that in a mirror "you look at yourself", Varda tests Jane's line of thought by having her look into the mirror. In the mirror, Jane can see Varda and her crew are there along with her reflection. Jane is not alone, rather she is on a stage where others look at her and validate her performance. Jane is not alone in the mirror because the mirror is not the only validation for her subjectivity. She must have the presence of others to make her subjectivity apparent. According to Lacan's idea of the Symbolic world, Jane must turn her head and see Varda and the camera to validate her being in the world. Jane disagrees with Lacan that the mirror is the only place to find solace without an audience. She is a celebrity who is constantly confronted with the camera which puts her on constant display (310 McFadden). She desires the Imaginary world — a world where she has one whole presence. However, she does not realize that her subjectivity cannot be whole and must be dependent on others.

Cléo, like Jane B., desires to live in the Imaginary world. To be a subject in the world would mean having to come to terms with the fact that she is dying. She must confront this disease and worries about it, but she enjoys her reflection as she sees it now. She wants to keep this singular whole perception of herself. She cannot escape the Symbolic world and wants to have a whole identity. To be a whole identity would mean being able to keep her beauty and to keep being alive. To face death and to lose that beauty would equate to being in the world and having to experience the disparity between the perfect reflection and the fragmented self. Early in the film, when looking at a mirror, she thinks to herself, "As long as I'm beautiful, I'm even more alive than others." (5:54) To her, being able to be beautiful as she sees herself in the reflection is to be alive and 
well. To be ugly and to face that she will die is the ultimate anguish. Again, Cléo would rather kill herself than to be ill and ugly.

The tension of wanting to be whole but wanting to be a subject in the Symbolic world is on full display when Cléo sings a song her two male composers have written for her. At 37:08, Cléo returns from her car ride through out Paris, France and settles into her apartment as her assistant, Angèle, and her composers surround her and pay attention to her. After going through the different songs they have written for her, she begins to sing "Without You" which is melancholic compared to the rest of her repertoire. It contains barren and deathly imagery which fills Cléo with despair as she sings. In one continuous shot, as Cléo begins the song, the camera starts to pan left at a crawling pace. As the camera continues to move closer to Cléo, her house guests, who first framed her, are no longer in the shot. Suddenly she is captured in a close up. She looks up from the music sheet and stares into the lens. As she continues singing, an obvious light shines on the left side of her face. In this moment, we are in Cléo's psyche, experiencing her turmoil of wanting to be the whole image. Even though we are inside her psyche, she is still surrounded by her house guests who are ratifying her reflection. The reflection is of her in their eyes. In this moment, Cléo is demonstrating the mirror stage.

The song highlights her worry of being a "wasted beauty" that is "cold and naked". She worries about not being able to live and be as beautiful as she is in this moment. She wants the reflection of her beauty right now to last. Yet, those around her ratify her into existence. They are the mother who brings the child into the world of language and subjectivity. It is the reflection she misses, and she can feel the gap between her and the mirror widen. The song constantly repeats the lyrics "without you". The 
"without you"s are significant to understanding both the mirror stage and Cléo's struggle because the phrase shows how Cléo has a dependency on the reflection and longs for it to define her. She needs it and cannot live without it. It is the basis of her Lacanian identity. Without her reflection, in a strict Lacanian sense, she would be lost and gone forever.

There is one line in the song that needs to be highlighted, though, that complicates Cléo's stagnant state in the mirror stage. Cléo mentions in her song that her body will "decay on a crystal bier." A bier is a resting place for a corpse before it is put into a coffin. The crystal bier mimics the mirror. Cléo can envision herself on a mirror, physically dead. People will be able to view her body, but she will not have a reflection to look at. There will be no whole reflection by which to recognize herself. The mirror and the big Other are surrounding Cléo, ratifying her into existence, but she literally cannot see her reflected self. The image of a dead Cléo on a crystal bier with the big Other surrounding her symbolizes the death of the reflection. Therefore, the image depicts the death of her being a subject in the world and the death of her Lacanian identity since the mirror stage cannot start without the child looking into the mirror and recognizing his reflection. Cléo, without knowing it, is highlighting the disruption of the mirror stage. If one, then, does not see their reflection in the mirror, can identity or subjectivity be formed?

Feminist theorists are vocal about the complex relationship between women and the mirror. For example, Gloria Anzaldua in Borderlands/La Frontera reflects on the mirror and the act of "seeing". She writes, "There is another quality to the mirror and that is the act of seeing. Seeing and being seen. Subject and object, I and she. The eye pins down the object of its gaze, scrutinizes it, judges it. A glance can freeze us into place; it 
can 'possess' us" (42). Similar to Lacan, Anzaldua contends that the gaze of another can be a mirror such as the gaze of the mother can act as a mirror for the child. However, Anzaldua brings up the idea of the gaze "freezing." The reflection can freeze the person looking into it and can freeze the subject in a time and place. The gaze has the capability of making a person an object—of making a person "whole". Anzaldua highlights her feminine pronouns when discussing subject and object implicating that the tension between the Symbolic and Imaginary world is a gendered experience. Lacan makes it apparent that the boy child can experience subjectivity as he defines it, but he does not mention the girl child's identity and subjectivity. Therefore, being in the world and gazing being possessive are a gendered experience. For women, subjectivity can be given, but the big Other who ratified it can take it away.

For Cléo, she has the company of her assistant and composers around her, ratifying her into existence. However, they keep her frozen in their sights. They put restrictions on her and judge her. They treat her as one-dimensional — as someone who is only beautiful and as someone who is only a child. She is called a "child" multiple times in the film. One of the more prominent times comes from her personal assistant Angèle. When they first sit in a cafe after Cléo goes to the psychic, Angèle thinks to herself that Cléo "[...]could be happy but she needs to be looked after. She's a child." Angèle looks after Cléo in that she guides her and helps her. She defines the ways of the world for her. She explicitly tells her not to wear a hat because it is bad luck to wear a new hat on Tuesday along with not going into an unlucky numbered car. She shapes her superstitions and how Cléo should view the world. Angèle also helps put Cléo's extensions back into place and helps get her changed in and out of her clothes perfecting her image 
consistently so that not a single hair is out of place. Cléo is shaped to look polished and feminine always by the help of her assistant. Angèle gives Cléo subjectivity and a Lacanian identity, but only with the Cléo she molds into the reflection.

Cléo is not necessarily defined by her talents or intellect. She does not have permission to mourn over the idea of her dying because she should not have to worry about trivial matters. To her company, she is just a pretty child who can sing. Her assistant possesses her subjectivity and directs her life in the way Angèle wants Cléo to act, to talk, and to perform. Cléo, then, exists at an intersection between living a life of the Lacanian subjectivity in which she desires the whole reflection that she has to perfect herself but must follow subjectivity as defined by her peers. They shape her reflection to resemble a child in a woman's body.

Cléo's unrecognizable reflection means the mirror stage is disrupted - the process is stopped. Sue Thornham, feminist and cultural studies theorist, touches upon the idea of the mirror stage and its complication for women's subjectivity. For her, women do not have a moment in the Imaginary world where they believe they are whole. She believes that there is "no Lacanian 'mirror phase' through which to imagine the self." (30) Returning to the example of the six-month-old child, the child enters subjectivity by first looking into the mirror, believing he is whole. Then he looks back at the mother (big Other) who ratifies the child as a being in the world. What happens, then, when a child does not recognize the reflection? And further so, if the child looks back, is verified that yes, this is your image and you are a being in the world - does that child, who has not experienced the Imaginary world, experience the mirror stage? I would argue that Thornham is saying the child does not. Thornham does not believe that women 
experience the mirror stage. Women do not recognize themselves in the reflection because their reflections were never experienced as a whole to begin with. Cléo's reflection is not of herself because it has been controlled and defined by others.

Cléo yearns to have this whole identity— to not be a fragmented being who will lose her beauty and her life, but who is to say that when she is looking into the mirror that she recognizes her reflection? After the scene where Cléo sings "Without You" she starts to "shed" herself by removing physical markers of her previously glamorous image. She sheds her hair extensions, her form fitting dress, and her make-up —elements that she tried to perfect in the mirror. She dons a black dress, a black hat (the one that her assistant advised her to not get and then to not wear) and leaves the apartment with no make-up. By removing these cosmetic markers, she disrupts her previous reflection. Before the clarity "Without You" provides her, Cléo would have tried making herself perfect by putting her dress into place and by fixing her hair trying to attain the whole reflection. I argue that Varda highlights in the scene that Cléo has never had that whole reflection. The idea of the whole reflection has only been imagined for her and placed for her. Lacan's idea of the mirror stage does not play out because Cléo does not have a reflection in which to "imagine the self."

Cléo slowly begins to realize that she may not identify with her reflection when she sees her first mirror after leaving her apartment. At 43:17 she brushes her hair and thinks, "I always think everyone is looking at me, but I am looking at myself. It wears me out." She then disrupts her thought process and her looking at the mirror and sees that no one is paying attention to her. No one is standing behind her to ratify this moment in the mirror. Cléo once again shows the disruption of the mirror stage by not having the Big 
Other tell her that this reflection is hers. She is suddenly allowed to form an identity that is beyond the reflection and beyond Lacanian limits. There is no one to guide her, create for her, or put her into place. She is able to create an identity that has no preapproval or and that is not whole in the first place. The reflection is always becoming and not stagnant.

Living a life beyond the mirror is most apparent at 1:08:54 when Cléo is on top of stairs at a park performing a song. Unlike her performance of "Without You", there is no visible audience and there is no close-up. There is also no stark black background or stiff body movement. The song is upbeat compared to the melancholic and dramatic tone of "Without You" (the tone, again, defined by her composers). The camera follows her movements in a medium shot as she strides through sidewalks and trees. She sheds off that other performance with this new song. Cléo performs the way she would perform if there was no one looking at her. She dances fluidly and jovially. Cléo is on a stage, but it is a stage where she does not worry about the big Other ratifying her into the Symbolic world based on a reflection they have deemed for her. For this short moment in the film, Cléo lives a life beyond the reflection.

Living a life beyond the reflection does not mean that Cléo's subjectivity is not formed by anything around her or the people around her. What is significant is that the mirror does not represent a wholeness or a whole identity to desire after. Cléo's identity is not frozen nor is it stolen in the reflection at this moment. Her identity cannot be simplified by always desiring what is in the mirror versus what is in the world. Cléo now recognizes that her life is beyond a mirror, a recognition that harkens back to key tenets of feminist filmmaking, especially those of Varda. Like Cléo in the park, Varda's 
filmmaking strives to allow a viewer (and I contend, particularly a woman viewer) to be themselves when watching the film. The life of the viewer exists beyond the idea of a mirror-like cinema. Identity may be formed when watching a film, but it is not the whole reflection to live by. Film is just a representation of different identities.

Varda's filmmaking further emphasize representational cinema by editing and filming cinematic disruptions of the mirror. She swings her camera along to the music (35:42), goes from color to black and white film (3:12), and repeats an edit of Cléo going down the stairs three times in a row (5:32.) The artistic decisions disrupt the viewer from the film, reminding them that they "remain themselves" when viewing.

\section{The Girl and Mirroring:}

Varda may be disruptive through cinematic language, but Ana Lily Amirpour's $A$ Girl Walks Home Alone at Night (2014) disrupts through her characters. Amirpour's film is rather seamlessly edited, and her camera shots do not necessarily cause the viewer to be taken away from the film as Varda exemplifies in her work. The surge in seamless edits is common in contemporary women directed films such as Greta Gerwig's Lady Bird or even mainstream action films such as Wonder Woman and Captain Marvel. At the surface level, Amirpour seems to create a film where one could be frozen and held in according to Varda's cinematic paradigm. I contend that it is Amripour's character of The Girl who disrupts the mirror stage, Lacanian identification, and mirror-like cinema.

The Girl, well, is a girl, but she is also a vampire. She lives a quiet life in a basement in the dangerous Bad City (a fictional city that is an intersection of Iran and Bakersfield, California) (9:02 Amirpour interviewed by Vice) She, however, protects those who are mercilessly harmed by the patriarchy who control the ins and outs of the 
town. She helps those such as Arash, a caring young man trying to stay financially afloat who she falls in love with, and Atti, the local prostitute who has dreams of leaving Bad City behind along with its unforgiving clientele such as Saeed the pimp and Hossein, a drug addict.

Before understanding how The Girl disrupts mirrors, it is important to understand how she breaks conventional characteristics and tropes of the vampire, but more so the twenty-first century vampire. According to Carmen Gomez-Galisteo's “Vampire Meets Girl" contemporary versions of the vampire focus "[...] on the monster that cannot prevent his condition, much to his chagrin [...]" (1-2) Gomez uses Edward from Twilight as an example of a vampire who was forced to become a vampire against his own will and actively decides to only feed on the blood of animals, not humans. He is a vampire who longs to be human and cherishes mortality. The twenty-first century vampire, and monster for that matter, are creatures who treasure nothing more than to be human again. The popular trope is common in media such as The Vampire Diaries and Teen Wolf along with the late 20th century film Interview with a Vampire. The mainstream concept of these creatures define and shape our definitions of a monster who desires humanity. The vampires are relatable to an audience because they desire to be human and exhibit human-like qualities such as interests in popular media and general care for humans.

The Girl, though, does not mind being a monster. That is not to say The Girl does not exhibit human qualities. She collects posters and listens to music. She desires to be in a relationship with Arash and cares about the people she protects. She does not hate her monstrosity though. Her monstrosity develops a form of (questionable and critique-able) activism for those who are abused by patriarchal standards. The Girl keeps her vampirism 
a secret, but also feels no remorse for killing the men she seeks out. She steals from the people she kills as they lay on the floor dying to the point where she has hordes of jewels and CDs as momentum. She does not exhibit any internal conflict for deciding to kill, and only feels ashamed when she believes Arash will not like her if he were to uncover her secret. Being a vampire is not a burden or a struggle like her twenty-first century counterparts might feel. Being a vampire is a part of who she is.

Being a vampire also comes with familiar tropes, though. She is only ever seen walking at night, she has fangs, and she drinks blood. She, more importantly, does not have a reflection. She does not have a "mirror phase to imagine the self." (30 Thornham) The Girl disrupts the mirror stage by not having a reflection. Cléo is a human who can look into mirrors and can seemingly have a Lacanian identity. The Girl literally cannot look into the mirror because she is a vampire and does not have a reflection to look at. Not once does her reflection show up on a window nor does it show up in someone's vanity. The Girl, by default then, disrupts the mirror stage for herself. However, it does not mean that she is not capable of participating in the process.

The Girl has no reflection but acts as a mirror to those around her. It appears the citizens of Bad City such as Arash and Atti experience the mirror stage. Arash can see his rebelliousness reflected in the Girl. Atti sees a woman outcast only walking in the dead of night reflected in The Girl as well. They find their reflection in her and are ratified into subjectivity because of her as well. It is as if she is the mother in Lacan's example of the mirror stage. Arash and Atti are the child who recognize their reflection in The Girl and The Girl reaffirms that they are their reflection. She affirms by opening a dialogue with them and caring for them - a gesture she does not extend to other citizens of Bad City. 
Through The Girl, they are able to experience the mirror stage and have a Lacanian identity.

Do Arash and Atti experience the mirror stage, though? The Girl is the mirror and the big Other, but she is a fragmented mirror. She is a broken mirror who cannot represent a seemingly whole reflection to desire after. For example, with Atti, The Girl can present her with a whole reflection of this woman who experiences the margins and the threat of male violence, but it is not the case. Whether or not she reflects it to others, The Girl has control of Bad City. The Girl threatens a young boy in the middle of the night and steals his skateboard from him. Neither of these examples are Atti's reflection. The Girl is only able to give fragmented reflections to the people around her thus disrupting their mirror stage process. The fragmented reflection indicates that neither Atti or Arash have a whole reflection to desire for-meaning that The Girl can only give representations and never a seamless reality.

The Girl's disruption of womanhood, her femininity, and how she performs it also represents the fragmented reflection. First off, she is a disruption to the heteronormative reproductive timeline. In "The Vampire, the Queer, and the Girl," Kimberly Lau discusses how the vampire themselves are "queer" because they defy time thus defying human notions of having a life worth "living" for such as marriage and reproduction (4). The Girl follows the same line of disruption. Let us consider the mirror stage again and how the Girl cannot experience it. Her subjectivity and identity are not defined by the gaze of others. Neither would she define herself to gender expectations and societal expectations to be a woman in Bad City. 
Her main point of reference is Atti. Part of Atti's job is to perform feminine standards that would garner her attraction of another man. Atti is always seen, even in her own home, in heavy makeup. Atti is judged on how she is beautiful for her age, but that she is becoming old (14:05). So, when Saeed, the pimp of Bad City, one day abuses Atti in his car and does not pay her for her service, The Girl decides to personally seek him out and grab his attention the only way she can — by performing femininity. At 18:13, The Girl is in a similar shot to Cléo where she is trying to "perfect" herself, but the main difference is The Girl is not using a mirror, but rather mimicking the actions. The difference between mimicking and reflecting is that mimicking connotes incompleteness compared to the Lacanian whole reflection. The Girl mimics femininity to get what she desires but does not necessarily need femininity to survive like Atti. The Girl is in a medium close-up applying strong eyeliner and dark lipstick — trademarks of Atti and the Madonna poster in her bedroom. On the surface, putting on the makeup conforms to the gendered standards of Bad City. Embodying Atti's reflection, as mentioned earlier, leads the viewer to believe she is putting on makeup for attention of men and for sexual desire. However, for The Girl, it is not the case. Again, The Girl embodies the fragmented reflection and so her reflecting femininity means that femininity cannot be whole. It is broken. Her motive is not to please, and it is not to perfect herself for others. She understands that in order to grab Saeed's attention, she must perform and mimic femininity. She reflects femininity on the surface but does not need to live or survive on feminine conventions like Atti does. She performs to enact her desires - to kill, to feed, and to protect. 
The Madonna poster must be highlighted because it further explores the idea of a reflections versus a representation. Again, I argue that a representational cinema is one that does not define as one whole perspective, but rather provides an angle to a subjective experience. Representational cinema is like the fragmented mirror in that sense because the representation cannot present a whole reflection. So, the Madonna poster exemplifies the fragmented mirror. Madonna the popstar does present an image of sexuality and femininity that The Girl utilizes to mirror femininity, but the picture of Madonna is also not of Madonna herself. As Lily Amirpour points out in the behind the scenes video, the poster mimics Madonna's first album cover, but the face is that of Margaret Atwood (3:52 Vice). Even the poster itself is not a whole reflection of Madonna. It is just a representation of her in Bad City. The audience will recognize the iconography of the popular album cover but will not realize that it is a representation of it, not a reflection. The audience is deceived by the fragmented reflection, which also happens to those who rule the streets of Bad City.

How does the patriarchy of Bad City see The Girl as a mirror? For Saeed, he mostly accepts the reflection and then is utterly confused. After putting on makeup, The Girl tricks him into taking her into his apartment. The reflection has deceived him, and he believes that she sexually desires him. In his home, he freely does his normal activities (exercises, does drugs, and even dances to his music.) His walls are revealed to have taxidermy deer heads and a poster of a tiger to match his tiger throw cover on the couch. His home is littered with predator imagery. Throughout his routine, he believes this will be a reflection of his everyday life - a predator waiting to attack his prey. He believes he is in control of the situation just as he is in control of the streets outside. However, he 
experiences the disruption of this reflection. As he parties around his home, The Girl stands by the doorway very still and merely observes him. He asks her questions, but she does not answer. He shows that he is attracted to her by dancing provocatively, but she does not reciprocate. This confuses him, but he continues to act normally. Saeed believes The Girl reflects Atti, so he expects that she will act just the same. He believes she is a whole reflection of Atti. Her actions (or inactions for that matter) disrupt him because she is not acting as Atti. She does not bend to his will or sexual advances. He is now entered upon unfamiliar territory.

It is when she is able to lure him into a corner of his house that the fragmented reflection shows more clearly. At 23:24, they stand close together in a moment of seeming intimacy and mutual observation. In a familiar, erotic moment, Saeed has every reason to believe that The Girl, like Atti will bend to his sexual desires and patriarchal power. In other words, Saeed believes that The Girl's presence reflects the typical maledominated life he leads in Bad City. Under this pretense of undisturbed reflection, he mirrors a previous movement that he performed on Atti where he slides his finger over The Girl's face with the intention of putting it in her mouth. But because she does not reflect the supposedly whole world Saeed occupies, but rather represents the fragmentation of those normative gender roles, she foreshadows the consequences of believing a whole reflection exists.

As he inches towards her mouth, she bares her fangs. He is immediately disrupted from the reflection afraid to lose his finger. He is taken out of the moment and is now in an unfamiliar and dangerous territory. There is a fear to be harmed and to no longer be in control. Again, Saeed has always been a force to be reckoned with and no one challenges 
his control over Bad City. He is taken aback from this fragmented reflection that challenges his presupposed whole identity. Beckoning him, she grabs his hand and invites to take one more jab at her mouth — a silent gesture to convince she is still a reflection of his prey. He allows himself to believe it, but then is ultimately (and mortally) disrupted when she takes a bite out of his finger and then ends his life. Saeed has fallen for the idea of a whole reflection. He has believed that this figure who looks like Atti must mimic Atti and her movements, and he suffers the consequences for believing so

Another patriarchal figure who suffers from the fragmented mirror is Hossein, Arash's father. Up to the point of Hossein's and The Girl's first interaction, Hossein is a character to be pitied. He is always under the influence of drugs, he is always in need of his son's help for financial and day to day responsibilities, and he seems to not be able to be a parental figure to Arash. It appears that he too might be an outcast of Bad City. However, he has patriarchal control of the streets unlike his son and others. He is able to freely roam the city and most of all, he feels he can harass Atti into allowing him to have sex with her without paying in return. After harassing Atti, Hossein notices The Girl across the street (33:42). The camera focuses in and it is clearly seen that she is glaring at him. Hossein beings to walk and The Girl follows suit. The Girl begins to imitate his pauses and paces. She copies his exact movements. She begins to mirror him. Hossein at first does not recognize that his actions are being mimicked. He does not recognize the reflection being presented. Just like Saeed, there is a confusion of what is being shown to him. When Hossein realizes he is being reflected, he is taken aback and is disrupted, but, even more so, he is filled with anger. 
The anger could be deemed by what Lacan would call "aggressivity". Lacan's aggressivity is defined as an "alienating identification"(61 Fong). Aggressivity occurs when there is a large disparity or gap between the reflected image and the fragmented being in the world. The disparity leaves the individual anxious for the whole reflection. Hossein's confusion and aggression are not merely the anxiety of the reflection versus his fragmented self, though. It is the emasculation represented when he realizes that someone like The Girl can be his reflection. The Girl who reflects the outcasts and those who are in the margins are now reflecting him. The identity he has developed and the control he thinks he possesses are now in the reflection of a petite woman. Now his control is being questioned. His self-recognition is being disrupted. Seeing his reflection in The Girl creates an existential crisis. Hossein does not have total control of the streets in Bad City because he even cowers to Saeed's will and demands. Hossein relies on the power he gets with Atti to feel a semblance of patriarchal control and control of his own life and addiction. When Hossein sees The Girl mirror his movements, he develops a crisis in which he realizes that he does not have control he thinks he has.

When The Girl reflects the patriarchy, ultimately masculinity experiences a disruption. Saeed loses his control and power to the Girl. Hossein loses himself and what little semblance of patriarchal agency to the Girl as well. To be masculine in Bad City is to feel at ease on the streets at night and it is to have control over those who are not masculine or masculine enough. The Girl's fragmented reflection disrupts the notion that they ever had control at all. Those who are allowed masculinity and power are not as whole as they believe they are. Their masculine identities are fragmented, and The Girl puts it on display. 
Regarding the film itself, The Girl is a metaphor for cinema. Viewers perceive the cinema as mirror-like. They believe the narrative and the protagonists represent them just as the citizens of Bad City believe The Girl seems like a reflection of them. That is a facade though. Just as Saeed is deceived by The Girl's reflection, cinema deceives the viewers as a mirror. As Varda would say, cinema is a reproduction. The Girl only reproduces what she sees, but she is not the whole reflection. As both Cléo from 5 to 7 and A Girl Walks Home Alone at Night reveal, there was never a whole reflection to begin with. With cinema, there is no whole reflection to experience the mirror stage for anyone for that matter because cinema is a fragmented reflection. Therefore, cinema is a representation of certain realities because it cannot capture a whole reflection.

\section{Conclusion:}

At the 2020 Oscars, considering once again that it was a monumental year for women representation and for women directed films, award recognition is scarce. One can easily believe from the nominations that women directed films did not garner the representation and achievements it did. If men dominated films are supposed to be reflections of our time, one can easily see one whole perspective to identify with considering their mass recognition and permeation through culture. If suddenly a viewer recognizes that cinema is merely just a representation or a fragmented reflection, the mirror is broken. There are different subjective views in which to watch and in which to interject. Film might lend a hand at self-identification and that one might feel recognized in film, but it does not mean one's subjectivity is defined by the whole reflection.

Cléo from 5 to 7 presents insight to how Varda's character Cléo wants the whole reflection and feels that it is her end all be all but discovers she can live a life beyond it 
and can be satisfied from doing so. A Girl Walks Home Alone at Night presents us with a Girl who acts as a mirror, but presents fragmented reflections to those around her, thus creating a reflection that can only ever be representation. These films and the women directors behind them represent a cinema in which viewers will be able to put the mirror aside and see a reproduction of one's creative work. 


\section{References}

A Girl Walks Home Alone at Night. Dir. Ana Lily Amirpour. Kino Lorber, 2014. Kanopy.

Abdi, Shadee, and Bernadette Marie Calafell. "Queer Utopias and a (Feminist) Iranian Vampire: A Critical Analysis of Resistive Monstrosity in A Girl Walks Home Alone at Night." Critical Studies in Media Communication, vol. 34, no. 4, Oct. 2017, pp. 358-370. EBSCOhost, doi:10.1080/15295036.2017.1302092.

Anzaldúa, Gloria. Borderlands/La Frontera: The New Mestiza. 3rd ed. San Francisco: Aunt Lute, 2007.

Austin. "The Joker - A Haunting Reflection of Our Modern World." Renegade Radio, 7 Oct. 2019, renegaderadio.net/2019/10/07/the-joker-a-haunting-reflection-of-our-modernworld/.

Cléo From 5 to 7. Dir. Agnès Varda. Janus Films (The Criterion Collection), 1962. Kanopy.

Evans, Dylan. An Introductory Dictionary of Lacanian Psychoanalysis. BrunnerRoutledge, 2003.

"Feminism and Film: Critical Approaches." Camera Obscura: Feminism, Culture, and Media Studies, vol. 1, no. 1, 1976, pp. 3-10., doi:10.1215/02705346-1-1_1-3.

Fong, Benjamin Y., "Aggressivity in Psychoanalysis (Reprised): Jacques Lacan and the Genesis of Omnipotence." Death and Mastery: Psychoanalytic Drive Theory and the Subject of Late Capitalism, Columbia University Press, New York, 2016, pp. 59-78. JSTOR, www.jstor.org/stable/10.7312/fong17668.7.

Frisby, Erica. “'Joker' Reveals a Reflection of Madness.” Grit Daily News, 14 Oct. 2019, gritdaily.com/joker-film-reveals-reflection-of-madness/.

Gomez-Galisteo, M.Carmen1. "Vampire Meets Girl: Gender Roles and the Vampire's Side of the Story in Twilight, Midnight Sun and the Vampire Diaries." NeoAmericanist, vol. 5, no. 2, Jan. 2011, pp. 1-6. EBSCOhost, search.ebscohost.com/login.aspx?direc= true $\& \mathrm{db}=$ hus $\& \mathrm{AN}=67675234 \&$ site $=$ eds-live.

Hartwig, Martin. "Joker (2019) Film Review - A Dark Reflection of Our Broken Society." The Unshackled, 8 Nov. 2019, www.theunshackled.net/recourse/joker2019 review

Inclusion Initiative. "2019 Statistics." Women and Hollywood, www.womenandhollywood.com/resources/statistics/2019-statistics/

“Interview: Agnès Varda.” Film Comment, 29 Mar. 2019. 
Jane B. Par Agnes V. Dir. Varda, Agnes. Arbelos Films, 1988.

Lacan, Jacques. Ecrits. Ed. Du Seuil, 1999.

Lau, Kimberly J. "The Vampire, the Queer, and the Girl: Reflections on the Politics and Ethics of Immortality's Gendering." Signs: Journal of Women in Culture \&

Society, vol. 44, no. 1, Oct. 2018, pp. 3-24. EBSCOhost, doi:10.1086/698274.

McFadden, Cybelle H. "Reflected Reflexivity in Jane B. Par Agnès V." Quarterly Review of Film and Video, vol. 28, no. 4, Aug. 2011, pp. 307-324.

Moi, Toril. Sexual/Textual Politics: Feminist Literary Theory. London ; New York: Methuen, 1985.

Mulvey, Laura. "Visual Pleasure and Narrative Cinema.” Screen, 1975.

Shahrokhi, Sholeh. Body Beautiful: Making the Figure of Women in Film, Contemplation on the Iranian New-Wave Cinema of the Past Decade. 2009.

EBSCOhost, search.ebscohost.com/login.aspx?direct=true \&db=edssch\&AN=edssch.oai\% 3aescholarship.org\%2fark\%3a\%2f13030\%2fqt92f6p1p 8 \&site=eds-live.

Thornham, Sue. Feminist Theory and Cultural Studies: Stories of Unsettled Relations. Arnold, 2000.

Wiegand, Chris. French New Wave. Vol. [New ed.], Summersdale Publishers Ltd, 2005. EBSCOhost, search.ebscohost.com/login.aspx?direct $=$ true $\& \mathrm{db}=$ nlebk\&AN=148718\&site =eds-live.

Vice. "Behind the Scenes: A Girl Walks Home Alone at Night (Part 2)," 2015 Youtube. 